\title{
KONSEP PENDIDIKAN ISLAM DALAM KELUARGA
}

\author{
Siti Yumnah ${ }^{*}$ \\ ${ }^{1}$ Sekolah Tinggi Agama Islam Pancawahana Bangil
}

\begin{abstract}
Islamic education is essentially the first place for conducting education in which each family interacts with one another to help one another in the good. More than that, personality becomes the main thing to prioritize in upholding religious values that actually existed in children when they were born. The family as the first madrasa needs to be supported by a family environment that firmly plants religious seeds on the basis of building noble morals in all elements of daily life. The role of parents is very urgent to have a significant influence in paying attention to physical and spiritual needs, such as clothing, food and shelter, which form a unified whole in family education.
\end{abstract}

Keywords: The family as the first madrasa, The role of parents, moral education

\begin{abstract}
Abstrak : Pendidikan Islam hakikatnya merupakan wadah pertama penyelenggaraan pendidikan yang mana masing-masing keluarga saling berinteraksi untuk saling tolong menolong dalam kebaikan. Lebih dari itu, kepribadian menjadi hal yang utama untuk diprioritaskan dalam menjunjung nilai keagamaan yang sejatinya telah ada pada diri anak ketika baru dilahirkan. Keluarga sebagai madrasah pertama perlu didukung oleh lingkungan keluarga yang secara tegas menanamkan benih religius dengan dasar pembinaan akhlak mulia di segala elemen kehidupan sehari-hari. Peran orang tua sangat urgen untuk memberikan pengaruh signifikan dalam memperhatikan nafkah lahir dan batin baik sandang, pangan dan papan yang menjadi satu kesatuan utuh dalam pendidikan keluarga.
\end{abstract}

\section{Kata Kunci : keluarga sebagai madrasah, peran keluarga, pendidikan akhlak mulia}

*Korespondensi Penulis: sitiyumnah30@gmail.com 


\section{A. Pendahuluan}

Manusia pada hakikatnya memiliki kepribadian yang dapat mengarah kepada jati diri makhluk menuju insan kamil yang mana merupakan manusia dalam hal jasmani dan rohani yang memiliki potensi berkembang secara logika dan muara akhirnya kepada ketaqwaan kepada-Nya. Berdasarkan hal tersebut, maka pendidikan Islam bercita-cita mencetak manusia yang lebih bermanfaat baik bagi dirinya dan orang lain dengan semangat beramal shalih untuk mendekatkan diri kepada Allah melalui hablun min Allah dan kepada manusia melalui hablun min an-nass sehingga dapat diambil manfaat yang berlebih dengan keadaan alam yang ada di sekitarnya untuk kepentingan hidup di dunia dan akhirat ${ }^{1}$.

Pendidikan Islam bertanggung jawab menjalankan pendidikan yang dapat menumbuhkan dan mengembangkan potensi yang ada pada peserta didik sebagai manusia yang membutuhkan bimbingan dan arahan untuk perkembangan aqliyah baik secara jasmani maupun rohani. Potensi tersebut perlu dijaga dan dirawat dengan mempertahankan nilai-nilai dan norma yang sejalan dengan agama Islam guna kebermanfaatan bagi segenap masyarakat dan lingkungannya.

Bagi ranah pendidikan, keluarga berperan penting dalam mengatur situasi lingkungan masyarakat Islam maupun non Islam yang merupakan wadah pertama dalam mendidik melalui proses tumbuh kembang seorang anak dalam menuju jati diri bangsa. Anak yang lahir dari sebuah keluarga akan terpengaruh dengan lingkungan keluarganya melalui interaksi antar anggota keluarga dan terjadinya proses peniruan yang membawa dampak nyata pada diri seorang anak. Dalam pada itu, anak akan mengalami masa kritis dimana pada usia balita atau usia pra sekolah yang muncul sebagai akibat dari adanya keingintahuan yang besar untuk menjalankan tugas manusiawinya dengan menanamkan budaya bertanya dan menjalankan apa yang dilakukan orang sekelilingnya serta tidak mudah untuk

\footnotetext{
1 Zakiah Daradjat, Ilmu Pendidikan Islam, (Jakarta: Bumi Aksara, 2014), hlm. 29-30.
} 
hilang dan berubah karena memori yang kuat. ${ }^{2}$

Menurut M. Tholhah Hasan, bahwa keluarga merupakan suatu wadah yang berisi anggota keluarga yang saling bekerjasama dengan ditandainya fungsi berkembang biak secara fisik dan mental untuk saling mempengaruhi, menjadi tauladan, mengolah kata secara linguistik serta panutan sikap dan perilaku yang mencerminkan nilai-nilai adab di dalamnya. Oleh karena itu, keluarga menjadi sebuah budaya yang akan membentuk keyakinan beragaman dan kebiasaan yang berjalan secara lokal dengan peran orang tua sebagai pengendali utamanya. ${ }^{3}$

Di era modern ini, pertambahan pengaruh dan tantangan akan semakin cepat dengan maraknya teknologi yang membawa perubahan besar terhadap sikap dan cara pendang seseorang dalam memperoleh pengetahuan. Di satu sisi, orang tua belum sepenuhnya menyadari akan pentingnya filterisasi yang dilakukan orang tua dalam ikut bertanggung jawab membentuk keluarga yang bermartabat dan menjalankan peran strategis membentuk sebuah pendidikan yang sesuai dengan tuntutan.

Pembinaan kepribadian anak harus dimulai dalam pendidikan keluarga sejak lahir bahkan perlu dimulai sejak di dalam kandungan. Hal ini sangat dipengaruhi oleh bagaimana orang tua memberikan pengaruh yang signifikan dengan amaliah doa untuk kebaikan janin yang ada dalam kandungan dengen memperdengarkan dan memperlihatkan sebuah perilaku yang baik dengan harapan akan diikuti oleh anak tersebut ketika telah lahir. ${ }^{4}$

2 Yusuf Muhammad Al-Hasan, Pendidikan Anak dalam Islam, (Jakarta: Yayasan AlSofwa, 1997), hlm. 10.

${ }^{3}$ M. Tholhah Hasan, Pendidikan Anak Usia Dini dalam Keluarga, (Jakarta: Mitra Abadi Press, 2009), hlm. v

${ }^{4}$ Zakiah Daradjat, Ilmu Jiwa Agama, (Jakarta: PT Bulan Bintang, 2009), hlm. 69 


\section{B. Hasil Pembahasan dan Kajian}

\section{Pengertian Pendidikan Keluarga}

Usaha yang dilakukan seseorang dalam bidang pendidikan guna memberikan tanggung jawab berupa pengembangan kepribadian disebut sebagai sebuah pendidikan. Usaha tersebut bervariatif yang salah satunya dilakukan dengan mengembangkan dan mengasah pengetahuan dan keterampilannya serta penanaman contoh yang harus diteladani melalui pemberian reward untuk meningkatkan motivasi belajar dan menanamkan pembiasaan beramal baik untuk bekal belajar sepanjang hayat. ${ }^{5}$

Undang-undang Republik Indonesia No. 2 Tahun 1989 tentang Sistem Pendidikan Nasional menyatakan bahwa pendidikan adalah usaha sadar untuk menyiapkan peserta didik melalui kegiatan bimbingan, pengajaran dan/atau latihan bagi peranannya di masa yang akan datang. Ki Hajar Dewantara sebagai bapak Pendidikan Nasional memberikan pandangan bahwa pendidikan membawa usaha mengedepankan budi pekerti luhur dengan mengasah pikiran serta menjaga keseimbangan fisik yang saling berhubungan untuk menjamin hidup yang sempurna dalam menopang keberhasilan baik secara dhahir maupun batin yang dapat diwujudkan dalam interaksi sosial yang baik serta mengedepankan budi pekerti yang selaras dengan pola hidup manusia yang harus dipupuk bersama untuk menjadi manusia yang utuh. ${ }^{6}$

Dasar sebagaimana dijelaskan di atas, memberikan pengertian bahwa pendidikan merupakan segala upaya yang dilakukan seorang pendidik melalui fasilitasi pengembangan kepribadian serta berkarakter yang mencerminkan pertumbuhan jasmani dan rohani dalam sebuah komunitas yang utuh melalui pendidikan lingkungan keluarga dan masyarakat yang turut mendorong peserta didik menuju kesempurnaan.

5 Dewi Istiana, Pengertian dan Tujuan Pendidikan Islam, (Semarang: Makalah, Fakultas Tarbiyah Institut Agama Islam Negeri Walisongo,2009), hlm. 2

${ }^{6}$ Abuddin Nata, Metodologi Studi Islam, (Jakarta: PT Raja Grafindo Persada, 2001), hlm. 290 
Disamping itu, pada tahun 1977 melalui Konferensi Pendidikan Islam Pertama (First World Conference On Muslim Education) memberikan kontribusi pemikiran bahwa pendidikan Islam merupakan totalitas yang menjalankan peran tarbiyah yaitu mendidik pada proses berkembang, ta'lim yaitu melakukan transformasi ilmu pengetahuan serta ta'dib yaitu mewujudkan perilaku yang berakhlak mulia. $^{7}$

Kata pendidikan dalam Islam merupakan sebuah bentuk tarbiyah yang dalam bahasa Arab diambil dari tiga akar kebahasaan yaitu rabba yurabbi tarbiyyan tarbiyatan yang memiliki makna bertambah (rabaa atau zad) dan berkembang (numuw). Konsep ini dijadikan sebuah dasar untuk membentuk dan memberikan segala tindakan secara tarbawi untuk menciptakan generasi yang berkarakter Islami dengan mengedepankan akhlakul karimah. Pengertian ini seperti yang terdapat dalam surat ar-Rum ayat 39 yang berbunyi :

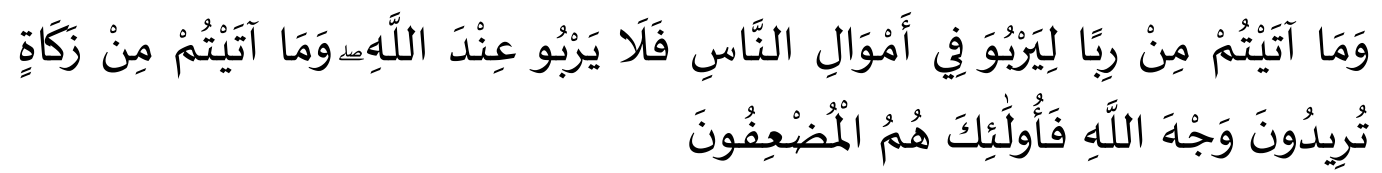

Artinya :Dan sesuatu riba (tambahan) yang kamu berikan agar Dia bertambah pada harta manusia, Maka riba itu tidak menambah pada sisi Allah. dan apa yang kamu berikan berupa zakat yang kamu maksudkan untuk mencapai keridhaan Allah, Maka (yang berbuat demikian) Itulah orang-orang yang melipat gandakan (pahalanya). (QS Ar-Rum 30:39)

Kata tarbiyah memberikan arah bagaimana pendidikan karakter sangat dioptimalkan dalam proses belajar mengajar dengan mengasuh dan membimbing menuju kesempurnaan peserta didik. Anak yang berada di masa belajar membutuhkan bimbingan agar dapat mengolah potensi otaknya dan hatinya untuk menjalankan peran manusia pada umumnya.

Sementara itu, kata ta'lim berasal dari kata 'allama yang dalam hal ini memiliki makna pengajaran atau transformasi ilmu pengetahuan. Menurut

7 Ahmad Tafsir. Ilmu Pendidikan Dalam Prespektif Islam. (Bandung: PT Remaja Rosdakarya, 2000). HIm. 28 
Muhammad Rasyid Ridha yang dikutip dalam Abdul Mujib dan Jusuf Muzakkiar memaknai ta'lim dengan proses transmisi atau perpindahan ilmu pengetahuan yang harus dituangkan melalui pendidikan guna memberikan bekal yang cukup untuk menjadi manusia dewasa. ${ }^{8}$

Kemudian kata ta'dib berasal dari kata addaba yuaddibu ta'diban yang berarti mendidik, melatih disiplin dan tunduk kepada segala aturan yang berlaku. Ta'dib secara sempit bermaksud mendidik akhlak, budi pekerti dan pada akhirnya akan bermuara menjalankan peradaban yang Islami. Muhammad Naquib Al-Attash mempertahankan penggunaan ta'dib sebagai model pendidikan Islam yang dalam hal ini lebih kepada pendidikan akhlak mulia ketimbang tarbiyah yang hanya membimbing menuju kedewasaan berfikir dan bertindak sebagai bentuk pendidikan yang sebenarnya. ${ }^{9}$

Berdasarkan keterangan tersebut, maka pendidikan Islam hakikatnya merupakan usaha sadar dalam menjalankan proses mengarahkan dan membimbing perilaku agar tercapai kepribadian yang selaras dengan ajar Islam melalui latihan dengan memfungsikan indra yang dimiliki. Upaya tersebut dilakukan untuk mengembangkan potensi individu sehingga dapat difahami esensi pendidikan Islam secara menyeluruh. ${ }^{10}$

\section{Pengertian Keluarga}

Keluarga merupakan sebuah komunitas antara laki-laki dan perempuan yang diikat dalam hukum dan dilindungi oleh sistem perundang-undangan perkawinan yang sah. Sistem dalam keluarga memungkinkan terjadinya interaksi pendidikan awal dan menjadi urgen dalam hubungan orang tua dan anak yang sekaligus menjadi pondasi utama yang dapat dijadikan rujukan pada pendidikan

${ }^{8}$ Abdul Mujib dan Jusuf Mudzakkir. Ilmu Pendidikan Islam. (Jakarta: Kencana Media Group, 2008). Hlm. 227

${ }^{9}$ Ahmad Tafsir. Op.Cit..., Hlm. 26-27

10 Haidar Putra Daulay. Pendidikan Islam Dalam Sistem Pendidikan Nasional di Indonesia. (Jakarta: Kencana, 2004). Hlm. 153 
formal11. Oleh karena itu, apa yang terjadi dalam sistem pendidikan dalam keluarga menjadi bagian informal yang bertanggung jawab dalam membentuk pribadi anak secara dini dengan memelihara dan merawat akhlak yang menjunjung tinggi rasa hormat untuk ditumbuhkembangkan dalam interaksi dalam keluarga itu sendiri. Interaksi dalam pendidikan keluarga harus ditekankan sedini mungkin agar tercapai tujuan hidup berkeluarga.

Menurut Zakiah Daradjat terkait dengan konsep keluarga yaitu sebuah tempat pertama yang berfungsi menumbuhkan dan mengembangkan kepribadian anak yang mana situasi dan suasana harmonis akan terbentuk jika diwujudkan dalam kondisi yang nyaman dan menyenangkan. Namun jika hal ini tidak terjadi, maka situasi belajar dan perkembangan kepribadian juga terhambat ${ }^{12}$.

Sementara itu, menurut Djamarah bahwa keluarga merupakan sebuah institusi yang terbentuk karena sebuah ikatan perkawinan antara dua insan yang berbeda dengan terjadinya kemungkinan perbedaan budaya, oleh karena itu hidup akan berdampingan dalam mewujudkan sebuah pasangan yang sah dan terajut dalam sebuah ikatan perkawinan yang secara tidak langsung adanya kesepakatan antar dua budaya yang diperlukan adanya saling memahami antara keduanya sehingga tercapainya sakinah mawaddah wa rahmah ${ }^{13}$.

Pendidikan keluarga yang digaungkan oleh Ki Hajar Dewantara merupakan sebuah wadah penyelenggaraan interaksi sosial yang terjadi proses belajar mengajar di dalamnya dengan memprioritaskan kepada penyediaan sarana dan prasarana yang memadai untuk terciptanya budaya belajar yang efektif guna mewujudkan manusia yang sempurna. Dengan demikian keberlangsungan pembentukan watak individu akan dapat diperoleh jika pembangunan budi

11 Mansur. Pendidikan Anak Usia Dini Dalam Islam. (Yogyakarta: Pustaka Pelajar, 2005). Hlm. 318

12 Zakiah Daradjat. Pendidikan Islam Dalam Keluarga dan Sekolah, Cet. 1 (Jakarta: Ruhama, 1994). Hlm. 47

${ }^{13}$ Syaiful Bahri Djamarah, Pola komunikasi Orang Tua dan anak dalam Keluarga, Jakarta: Rineka Cipta, 2014), hlm. 18. 
pekerti tersedia dalam hidup bermasyarakat ${ }^{14}$.

Konsep keluarga dalam al-Qur'an dapat dijumpai melalui penggunaan istilah yang berbeda-beda namun tetap mengarah pada satu makna. Diantaranya kata Ahlul Bait yang mana merupakan penyebutan untuk keluarga Nabi Muhammad Saw sebagaimana diterangkan dalam surat al-Ahzab ayat 33. Kata tersebut juga dapat bermakna meluas dengan wilayah faraid atau pembagian harta warisan yang selalu mengiringi kondisi pasca adanya keluarga yang meninggal. Disamping itu, keluarga juga berpotensi mewujudkan ikatan cinta dan rasa kasih sayang yang menurut Abu Zahra juga merupakan institusi yang terdiri dari seorang lelaki dan istrinya beserta anak-anak dan keturunannya serta orang yang dinafkahi seperti kakek, nenek dan lain sebagainya. ${ }^{15}$

Berdasarkan keterangan sebagaimana di atas, maka konsep keluarga merupakan satu kesatuan masyarakat kecil yang berisi anggota keluarga dan proses pembentukan pendidikan kepribadian yang perlu pendampingan secara optimal dan muara akhir adalah terbentukan manusia yang sempurna yang dapat mengoptimalkan akalnya dalam meraih masa depan. Kesempurnaan akan diperoleh seorang anak jika dilakukan berdasarkan ajaran Islam dengen mengedepankan akhlak yang mulya serta menjaga adab yang berbentuk alur belajar yang santun serta adanya adab dan tata krama yang dilakukan dan diteladani di dalam hubungan keluarga.

\section{Fungsi Keluarga}

Dinamisasi keluarga dalam menata dan menjadikan lingkungan sebagai sarana belajar bukanlah hal yang mudah. Oleh karena itu, diperlukan upaya yang sungguh-sungguh dalam mengolah kepribadian yang baik untuk terciptanya hubungan yang baik sebagai bekal kehidupan setelah proses pendidikan.

14 Ki Hajar Dewantara. Bagian Pertama Pendidikan. (Yogyakarta: Majelis Luhur Taman Siswa Cet II, 1977). Hlm. 374

15 Mufidah Ch. Psikologi Keluarga Islam Berwawasan Gender. (Malang: UIN Press). HIm. 37-38 
Soelaeman sebagaimana dikutip oleh Uyo Sadullah menjelaskan tentang fungsi keluarga yang dalam hal ini beliau membagi fungsi tersebut sebagai berikut:

a. Fungsi Edukasi

Fungsi edukasi pada fase ini dapat berbentuk wahana pendidikan anak yang tergolong dalam lingkungan keluarga yang sama-sama belajar yang diwujudkan melalui dampingan orang tua untuk kebaikan anak-anaknya yang tersedia di dalamnya sarana dan prasarana belajar dan pembangunan wawasan yang memadai agar tercipta suasana nyaman dan menyenangkan. ${ }^{16}$

Seorang anak akan memandang sebuah keluarga menjadi wadah pendidikan yang pertama kali ditemui sejak lahir yang dalam hal ini bermula nilai-nilai luhur, keyakinan dalam bersikap, pembangunan akhlak mulia serta belajar bagaimana memulai berbicara serta belajar menulis dan bersosialisasi. Dalam pada itu, anak-anak juga belajar kepada orang tua dalam hal melihat, mendengar, menyentuh dan melakukan suatu hal yang dilakukan melalui proses meniru.

b. Fungsi Sosialisasi

Dunia anak identik dengan dunia bermain yang mana lingkungan pendidikan efektif dalam keluarga harus dapat mengenalkan suasana yang menarik dengan kehidupan sosial yang dapat menjamin interaksi sempurna di kalangan anak-anak. Dalam pada itu, pembentukan karakter dapat dijangkau dan diperoleh melalui komunikasi antara teman sebaya yang dapat mengerti satu sama lainnya walaupun stabilitas pribadi masih belum ditemukan pada diri anak seusianya.

Pembentukan fungsi sosial dengan mengenalkan bahwa di luar dirinya ada orang lain yang saling membutuhkan dan tempat untuk saling menyapa dan saling menolong. Kehidupan yang saling menghargai dan menghormati seakan menjadi keharusan untuk ditanamkan pada diri anak guna membentuk rasa tanggung jawab yang tinggi dan berperilaku jujur atas setiap tindakan dan

16 Uyoh Sadulloh. Pedagogik; Ilmu Mendidik.(Bandung: Alfa Beta, 2011). Hlm. 188 
perbuatan yang dilakukan. Lebih dari itu, diharapkan anak meneladani etika yang baik kepada sesama begitu juga kepada binatang dan tumbuhan. ${ }^{17}$

c. Fungsi Proteksi (Perlindungan)

Keluarga berfungsi sebagai wadah mendapatkan rasa nyaman, aman, tenteram dan damai bagi seluruh anggota keluarga dengan kebebasan untuk berekspresi untuk saling menghargai secara lahir dan batin serta terbudayanya saling melindungi antara anggota keluarga dan bekerja sama dalam memenuhi kebutuhan sandang, pangan dan papan untuk kehidupan bersama.

Seorang kepala keluarga yang sering disebut Bapak atau Ayah memiliki tanggung jawab untuk melindungi istri dan anak-anaknya dari segala ancaman yang datang dari luar serta berusaha memberikan rasa nyaman yang dapat memotivasi kehidupan yang harmonis. Perlindungan yang diberikan seorang kepala keluarga dapat meliputi keamanaan secara fisik dan mental serta ketahanan dalam memenuhi nafkah lahir dan batin dalam segala situasi. ${ }^{18}$

d. Fungsi Afeksi (Perasaan)

Dalam membina kehidupan berumah tangga, juga diperlukan fungsi afeksi yang dapat menumbuhkembangkan rasa cinta dan kasih sayang antar sesama anggota dan lingkungannya. Ikatan ini harus terus terjalin kuat dengan mengedepankan perasaan saling memiliki dengan fanatisme keluarga yang kuat diiringi mimik dan gaya bicara yang santun selaras yang disepakati oleh anggota keluarga dengan tidak adanya satupun yang merasa tidak nyaman dalam berinteraksi di dalamnya.

e. Fungsi Religius

Fungsi religius merupakan bagian dari tugas keluarga yang membangun anggota keluarga memiliki kesadaran religius dengan terwujudnya jiwa beragama yang kuat dengan didorong oleh keimanan dan ketaqwaan kepada Tuhan Yang Maha Esa serta berimplikasi kepada akhlak yang mulia dan berbudi

17 Uyoh Sadulloh. Ibid. Hlm. 189

18 Helmawati. Pendidikan Keluarga Teoritis Dan Praktis, (Bandung: PT. Remaja Rosdakarya, 2016). Hlm. 47 
pekerti luhur untuk menjadikan keluarga yang bermartabat.

Religius berkaitan erat dengan fungsi edukatif, sosialisasi dan proteksi yang menggambarkan adanya korelasi menunjukkan sikap santun dalam berinteraksi, menjaga diri dari perilaku menyimpang serta berupaya meningkatkan kesadaran belajar. Keluarga yang menjalankan fungsi religius, maka kehidupan keluarga akan memiliki kedewasaan dalam berbuat dan menjalankan norma agama yang memadai dalam berinteraksi sehari-hari. Dalam pada itu, agama akan membantu memecahkan persoalan yang dihadapi manusia dan lingkungannya terutama pada kehidupan selanjutnya. ${ }^{19}$

\section{f. Fungsi Ekonomi}

Fungsi ekonomi dalam kehidupan keluarga memberi ruang terhadap pemenuhan kebutuhan dasar sehari-hari baik secara ekonomi, fisik maupun materi yang dicerminkan dalam pola hidup efisien dan efektif. Fungsi ekonomi dapat dilihat dari aspek mencari nafkah serta mengolahnya dalam sebuah perencanaan yang matang serta memanfaatkan dan mengalokasikannya pada cara yang benar dan tepat.

Fungsi ekonomi hakikatnya berkaitan erat dengan pengaturan penghasilan yang diperoleh serta membelanjakannya di jalan yang benar dan maslahah. Kebutuhan rumah tangga dapat diukur dari seberapa hal tersebut bermanfaat bagi keluarga sehingga suami mampu mengatur pendapatan yang seharusnya diperoleh dan istri mengatur bagaimana pendapatan dapat digunakan sebaik-baiknya sesuai dengan target yang seharusnya. ${ }^{20}$

g. Fungsi Rekreasi

Fungsi rekreasi dalam keluarga dimaksudkan adanya kehidupan yang nyaman, menyenangkan dan ceria ketika melakukan interaksi dan melalui proses belajar di lingkungannya. Keadaan ini tentunya dapat dibangun manakala tercipta kerjasama yang baik antar anggota keluarga dengan suasana

\footnotetext{
${ }^{19}$ Ibid. HIm. 45
}

${ }^{20}$ Ibid. HIm. 46 
akur dan saling menghormati satu sama lain dengan orientasi pada saling memberi dan menerima. Rekreasi juga memiliki makna menjadikan keluarga sebagai hiburan bagi tumbuh kembang jiwa dan pikiran untuk selalu terajut keakraban antar sesama anggota keluarga.

h. Fungsi Biologis

Keluarga lahir dan tercipta dari adanya hubungan reproduksi yang tumbuh dan bersemi pada sebuah lingkungan kecil. Kebutuhan biologis merupakan fitrah manusia yang harus dijaga dan dipelihara dengan tentunya terlibatnya organ fisik untuk melestarikan kehidupannya. Fungsi ini termaknai sebagai kumpulan fungsi yang bermanfaat bagi keluarga untuk bersama mengatur dan membina kehidupan yang bermartabat dalam menghadapi tantangan serta mampu untuk beradaptasi dalam hidup di tengah masyarakat.

Manusia membutuhkan hidup yang berlangsung lestari melalui fungsi biologinya dengan memenuhi kebutuhan jasmani manusia yang menjadi kodrat berpijak. Dalam pada itu, manusia butuh kecukupan pangan, sandang dan papan yang memadai dan kebutuhan seksual yang menghasilkan keturunan. ${ }^{21}$

Berdasarkan keterangan di atas, maka keluarga merupakan kumpulan orang yang bersama-sama hidup dalam tempat tinggal yang sama dengan saling bekerjasama menciptakan interaksi yang baik serta menjalankan seluruh fungsi yang memenuhi kebutuhan dan tuntutan nilai yang baik. Tuntutan sosial dan agama menjadi indikator utama dalam membentuk pendidikan keluarga dengan hubungan saling menghormati dan menghargai untuk bersama-sama menuju kemajuan hakiki.

\section{Keluarga Dalam Pendidikan Islam}

Berbicara tentang keluarga, maka tidak dapat dipisahkan dengan pembahasan tentang perkawinan yang menjadi awal mula keluarga terbentuk. Dalam UU Perkawinan No 1 Tahun 1947 dinyatakan bahwa perkawinan adalah

21Ibid, hlm. 46 
sebuah ikatan lahir dan batin antara seorang pria dan wanita sebagai suami istri dengan tujuan membentuk keluarga yang bahagia dan sejahtera berdasarkan ketuhanan yang Maha Esa. Berdasarkan hal tersebut, maka anak yang dilahirkan dari proses perkawinan merupakan anak yang sah dan menjadi hak dan tanggung jawab orang tua untuk memberikan nafkah dan pendidikan yang layak serta memeliharanya untuk dapat berkehidupan yang layak. ${ }^{22}$

Pendidikan Islam memiliki posisi dan kedudukan yang sangat penting dalam berkehidupan berkeluarga yang dilalui berdasarkan prinsip tarbiyah yang akan memberikan pengalaman yang banyak untuk tumbuh kembang anak menjadi manusia yang sempurna. Dalam pada itu, sebagian anak belum mendapatkan haknya dalam meraih pendidikan yang memadai.

Walaupun begitu, tujuan utama keluarga adalah menjadi peletak dasar pendidikan dan penggembelengan akhlak yang dilaksanakan berdasarkan keyakinan agama. Kepribadian anak hakikatnya bergantung tabiat orang tua yang diambil pelajaran sejak masih kecil sehingga fitrah akan muncul sesuai apa yang mereka peroleh dari kehidupan sehari-hari yang mana mereka perlu melakukan kewaspadaan.

Jika merunut pada makna keluarga berdasarkan agama Islam, maka sejatinya tanggung jawab pendidikan yang perlu disadarkan dan dibina oleh kedua orang tua terhadap anak antara lain: ${ }^{23}$

a. Memelihara dan merawat serta membesarkan dengan penuh tanggung jawab melalui pemenuhan kebutuhan sandang, pangan dan papan serta perawatan harian secara berkelanjutan.

b. Melindungi dan menjamin kesehatan keluarga baik jasmani maupun rohani dengan membebaskan dari segala penyakit yang mungkin datang secara tiba-tiba dan membahayakan anggota keluarga.

c. Mendidik anggota keluarga melalui pendalaman pengetahuan dan

${ }^{22}$ Fuad Ihsan. Dasar-Dasar Kependidikan. (Jakarta: Rineka Cipta, 2008). Hlm. 62

${ }^{23}$ Hasbullah. Dasar-Dasar Ilmu Pendidikan. (Bandung: PT Raja Grafindo Persada, 2011). Hlm. 88-89 
keterampilan yang dimiliki serta mengamalkannya sebagai pelajaran berharga untuk menggapai masa depan ketika nanti telah menjadi dewasa.

d. Membahagiakan anak untuk menapaki kehidupan dunia dan akhirat dengan memberikan pendalaman agama yang kuat sebagai bekal tujuan akhir di akhirat kelak.

Tanggung jawab yang telah disematkan kepada kedua orang tua dalam mendidik anaknya, menjadi sebuah kesadarannya melaksanakan segala kewajibannya. Hal ini tidak dapat dipungkiri mengingat keluarga merupakan pendidikan pertama dan utama yang dapat berlangsung secara pasti melalui pembiasaan berakhlak mulia yang dipandu dan ditekankan oleh kedua orang tuanya agar semangat dan tanggung jawab dapat dilakukan secara optimal. Pengenalan pengetahuan hakikatnya juga diperoleh dari keluarga yang sepanjang hari dilalui bersama dengan berbagai keluh kesah yang dialami sang buat hati untuk mengadukan segala macam ancaman yang melanda. Oleh karena itulah, kepribadian utama dalam membentuk karakter anak adalah keluarga yang mana orang tua menjalankan peran dan fungsinya untuk membentengi keluarga dari segala hal yang mengganggu serta terciptanya hubungan saling mencintai dan menyayangi antar sesama anggota keluarga.

\section{Konsep Pendidikan Islam Dalam Keluarga}

Keluarga muslim sebenarnya merupakan benteng utama atau wadah anggota keluarga untuk dibesarkan berdasar pendidikan Islam. Dalam hal ini keluarga muslim dimaksudkan keluarga yang dijalankan aktivitasnya berdasarkan syariat Islam tanpa adanya penyelewengan yang dapat mempengaruhi keyakinannya. Adapun tujuan terpenting dalam membentuk keluarga muslim yaitu pelestarian generasi muslim yang bermartabat dengan mempertahankan dan memperjuangkan kehidupan muslim yang senantiasa ingat Sang Khalik. Disamping itu, pemenuhan kebutuhan akan cinta dan kasih sayang yang akan mewujudkan potensi suci yang sejatinya telah dimiliki ketika 
baru dilahirkan, dengan demikian pendidikan diarahkan untuk mempertahankan fithrah yang telah dimiliki sebelumnya. ${ }^{24}$

Berdasarkan keterangan sebagaimana di atas, maka orang tua diminta untuk benar-benar mendidik anaknya dan senantiasa memegang teguh tanggung jawab yang telah diemban sebagai insan yang telah siap meneriman tanggung jawab tersebut. Hal ini sebagaimana diterangkan dalam firman-Nya:

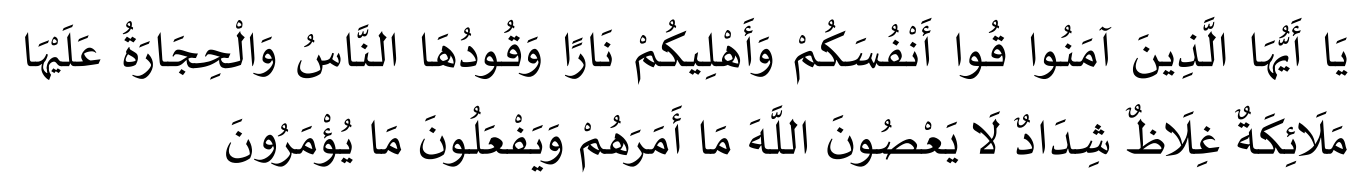

Artinya :Hai orang-orang yang beriman, peliharalah dirimu dan keluargamu dari api neraka yang bahan bakarnya adalah manusia dan batu; penjaganya malaikat-malaikat yang kasar, keras, dan tidak mendurhakai Allah terhadap apa yang diperintahkan-Nya kepada mereka dan selalu mengerjakan apa yang diperintahkan. (QS Tahrim 66: 6)

Ayat di atas menjelaskan betapa tanggung jawab orang tua dalam keluarga sungguh besar dimana menjaga keluarga dari mara bahaya dunia dan akhirat begitu penting untuk dilakukan. Dengan demikian keluarga sejatinya merupakan lingkungan pertama dan sepanjang hayat untuk terwujudnya pembelajaran yang selaras dengan kebutuhan individu dan anggota keluarga. Setiap individu membutuhkan keluarga tidak hanya pada saat masih kecil, namun juga ketika sudah tua renta pun juga membutuhkan interaksi yang baik sebagai bagian dari proses pendidikan. Pemeliharaan anggota keluarga akan berdampak buruk jika tidak diiringi dengan cinta dan kasih sayang. ${ }^{25}$

Berkenaan dengan ayat sebagaimana di atas, maka keluarga dalam Islam tetap mengantarkan pentingnya interaksi secara langsung dengan memberikan dorongan pengalaman dan mengenal ciri-ciri fisik sebagai bagian dari tumbuh

${ }^{24}$ Abdurrahman An Nahlawi. Pendidikan Islam Di Rumah; Sekolah dan Masyarakat. Cet ke-2. (Jakarta: Gema Insani Press, 1996). Hlm. 140-141

25 Hasan Langgulung. Manusia dan Pendidikan Suatu Analisa Psikologi, Filsafat dan Pendidikan. (Jakarta: Pustaka Al-Husna, 1986). Hlm. 348-349 
kembang anak. Pendidikan Islam mengenai keluarga senantiasa berlangsung melalui proses tumbuh kembang anak sebagai manusia yang beriman dan bertaqwa dengan mempertahankan akhlak mulia. Oleh karena itu, perilaku sebagai manusia yang terdidik diterangkan oleh ayat-ayat yang terdapat di dalam surat Luqman di antaranya ayat 13-14 yaitu:

\section{a. Pembinaan Iman dan Tauhid}

Kata tauhid berasal dari bahasa Arab yaitu wahhada yuwahhidu tauhidan yang berarti mengesakan atau menunggalkan Tuhan. Sementara maksud dari kata ini adalah upaya mengesakan Allah Swt sebagai Tuhan dengan benar-benar meyakini keesaan-Nya tanpa ada keraguan sedikitpun. Hal ini sebagamana dijelaskan dalam surat Luqman ayat 13 dengan memberi penekanan pada pencegahan atau preventif dari segala kesyirikan melalui tausiyah atau nasihat dan panutan untuk bertindak.

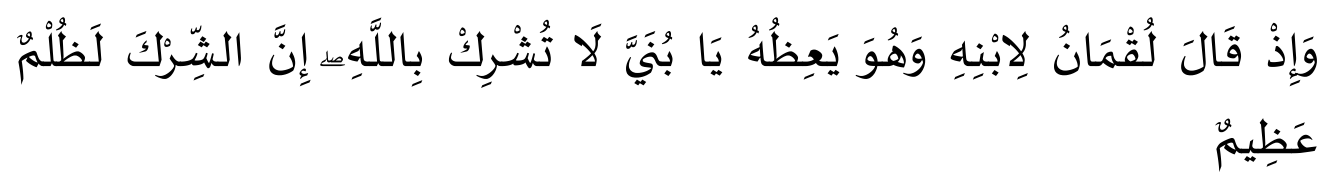

Artinya :Dan (ingatlah) ketika Luqman berkata kepada anaknya, di waktu ia memberi pelajaran kepadanya: "Hai anakku, janganlah kamu mempersekutukan Allah, Sesungguhnya mempersekutukan (Allah) adalah benar-benar kezaliman yang besar".(QS. Luqman (31): 13)

Ayat di atas menceritakan tentang keluarga Luqman Hakim yang melakukan upaya pencegahan dalam memberikan nasihat untuk tidak menyekutukan Allah Swt dengan segala apapun. Dalam hal ini, pendidikan penting dilakukan sejak dini untuk memberikan pemahaman akidah yang utuh sebelum anak mendapatkan banyak informasi ketika masuk di usia remaja. Pembangunan akhlak harus digalakkan pada usia emas agar memiliki prinsip yang kuat dalam menjalankan keyakinan yang benar.

Membangun semangat mempertahankan keimanan sejatinya telah dilakukan sejak dalam kandungan ibunya dimana sisi-sisi positif senantiasa 
dilakukan untuk kemudian kepribadian juga diikuti oleh sang janin tersebut. ketika anak telah lahir, maka pembangunan karakter juga terus dijalankan dan ditanamkan untuk menjaganya dari segala yang merugikan secara fisik maupun mental dan terlebih keimanannya. Perkembangan tersebut secara nyata dilakukan untuk membina akidah, akhlak, kecerdasan, mental serta estetika dalam menjaga keindahan dan merawak hubungan bermasyarakat. ${ }^{26}$

Pondasi iman yang menjadi dasar-dasar yang harus dipegang yaitu segala sesuatu yang berkenaan dengan hakikat keimanan baik kepada yang dhahir maupun ghaib dalam bentuk iman kepada Allah Swt, kepada malaikat, kitab-kitab Allah Swt, para rasul, hari akhir dan iman kepada qada' dan taqdir-Nya.27 Keyakinan ini sangat bergantung kepada seberapa orang tua mampu memberikan pendidikan agama yang kuat dan mendasar.

Kewajiban yang ditambatkan kepada orang tua merupakan keharusan untuk membantu tumbuh kembang anak dalam membentuk pemahaman iman dan ajaran Islam pada umumnya. Demikian ini akan berdampak kepada kesanggupan untuk menjalan kewajiban beragama dengan memberikan tuntunan dan tauladan yang benar dalam meyakinkan setiap apa yang diamalkan dalam kehidupan sehari-hari.

Pemahaman akan keimanan merupakan pondasi berakidah yang perlu dan harus dilakukan orang tua kepada anaknya dikarenakan mereka belum memiliki pemikiran yang mapan untuk menjaga stabilitas keimanan yang seharusnya difahami. Dalam pada itu, Abudin Nata menerangkan bahwa pendidikan agama dalam rumah tangga yaitu penanaman akidah dan keimanan yang menjadi dasar berperilaku yang harus ditanamkan sejak usia dini sehingga terjaga kekuatan lahir dan batinnya dan kuat menahan semua cobaan hidup. ${ }^{28}$

26 Zakiah Daradjat. Kesehatan Mental. (Jakarta: Gunung Agung, 1995). Hlm. 55

27 Kasyful Anwar Syarwani. Pendidikan Anak Dalam Islam. (Surabaya: Muara Progresif, 2014). Hlm. 24

${ }^{28}$ Abuddin Nata. Tokoh-Tokoh Pembaharuan Pendidikan Islam di Indonesia. (Jakarta: PT. Raja Grafindo Persada, 2005). Hlm. 332 


\section{b. Pembinaan Akhlak}

Pendidikan akhlak pada hakikatnya merupakan bagian urgen dari keseluruhan materi yang diajarkan di sekolah, dikarenakan pendidikan agama tidak lepas dari akhlak yang meneladani perilaku Rasulullah Saw dalam berdakwah dan mengarungi bumi ini dengan penuh dalam menyempurnakan akhlak yang mulia. Dalam hal ini perlu dikenal beberapa model sebagai berikut:

1) Pendidikan anak akan tampak dengan akhlak kepada orang tua dengan memperbanyak berbuat baik dan berterima kasih atas jerih payahnya membimbing dang mengarahkannya sebagaimana dijelaskan dalam surat Luqman ayat 14 yang berbunyi:

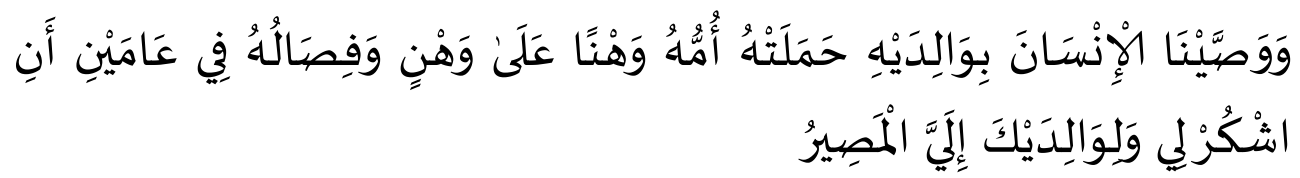

Artinya :Dan Kami perintahkan kepada manusia (berbuat baik) kepada dua orang ibu- bapanya; ibunya telah mengandungnya dalam Keadaan lemah yang bertambah- tambah, dan menyapihnya dalam dua tahun. Bersyukurlah kepadaku dan kepada dua orang ibu bapakmu, hanya kepada-Kulah kembalimu.(QS Luqman 31: 14)

Ayat di atas menjelaskan bahwa seorang anak harus taat dan hormat kepada kedua orang tua dengan berbuat baik serta bersikap santun untuk menjaga perilaku yang tercela.

2) Pendidikan Islam akan berimbas berbuat baik kepada orang lain dengan bersikap sopan dan santun dengan menjaga tata krama dalam bergaul, tidak sombong dan tidak angkuh, serta berjalan sederhana dan bersuara lembut. Sebagaimana difirmankan Allah dalam surat Luqman ayat 18-19.

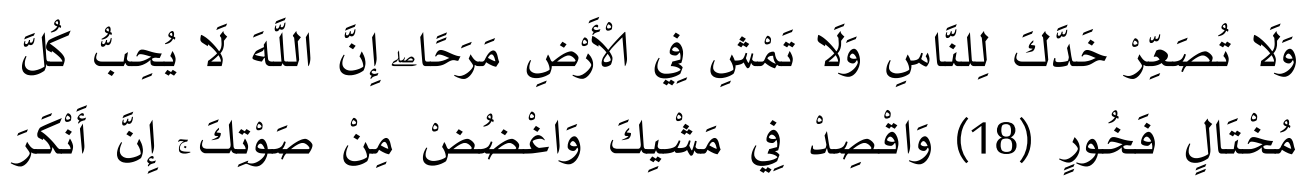




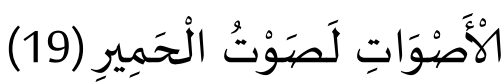

Artinya :Dan janganlah kamu memalingkan mukamu dari manusia (karena sombong) dan janganlah kamu berjalan di muka bumi dengan angkuh. Sesungguhnya Allah tidak menyukai orang-orang yang sombong lagi membanggakan diri. Dan sederhanalah kamu dalam berjalan dan lunakkanlah suaramu. Sesungguhnya seburuk-buruk suara ialah suara keledai.(QS Luqman 31: 18-19)

Ayat di atas memberikan gambarkan bahwa betapa pentingnya untuk berbuat baik kepada orang tua serta berterima kasih atas segala yang telah dilakukannya yang telah melahirkan dan membesarkannya dalam susah payah tanpa mengenal lelah yang kemudian dilanjutkan dengan menyusui dan sabar untuk merawatnya. Hal itu tidak lain agar anaknya tetap bersama orang tua dalam hal akidah dan amaliyahnya.

Pendidikan akhlak dalam keluarga lebih urgen diberikan dengan mencontohkan dan memberi tauladan kepada anak-anaknya guna diikuti dan dibiasakan untuk berperilaku yang sewajarnya berdasarkan tuntutan agama Islam. Oleh karena itu, orang tua bertanggung jawab penuh untuk mendidik anaknya dengan benar, sabar, istiqomah serta menolongnya jika ditemukan kesulitan dalam berproses. Disamping itu, orang tua bertanggung jawab membersihkan lidah anaknya dari perkataan yang dusta serta menjauhkannya dari berkata kotor yang mungkin akan diperoleh hal tersebut di luar. ${ }^{29}$

Orang tua memiliki pengaruh besar terhadap perkembangan anak dari aspek keterjagaan perbuatan dari segala yang dapat dikategorikan kenakalan remaja. Secara integratif keluarga akan membentuk proses pembentukan etika yang tanpa disadari akan muncul sebagai bagian dari interaksi yang dilakukan. Etika yang baik dapat dipengaruhi pengetahuan agama yang cukup sebagai bekal bersosialisasi untuk dapatnya berinteraksi yang baik kepada orang tua dan lingkungan sekitar untuk menuju kedewasaan dan menyadari akan pentingnya

\footnotetext{
${ }^{29}$ Kasyful Anwar Syarwani. Op.Cit. Hlm. 33
} 
berperilaku sesuai dengan susila yang dituntunkan dalam kehidupan nyata. ${ }^{30}$

Oleh karena itu, pendidikan akhlak menjadi faktor penting yang harus dipupuk dan disemai untuk mempertahankan perilaku yang baik. Pendidikan akhlak sejatinya harus dilakukan sejak usia dini agar benih-benih kebaikan dan kebenaran selalu hadir sejak kini untuk selalu didampingi oleh orang tua dan lingkungan menjadi orang yang berkepribadian yang baik dan santun. Akhlak yang mulia menjadi idaman setiap insan untuk menggapai cita luhur yang bernafaskan agama Islam.

Pembentukan karakter tidak bisa tidak harus dimulai dengan pembinaan akhlak mulia berdasarkan penanaman akidah yang dipupuk lingkungan keluarga. Hati yang baik akan menjadikan perilaku yang baik pula untuk dapat berinteraksi dan bersosialisasi dalam membangun jatidiri bangsa. Kebaikan yang ditanamkan pada diri manusia hakikatnya berisi ruh Ilahi yang didorong untuk menuju kesempurnaan, kondisi ini tentunya tidak akan dapat dicapai tanpa ditempuh melakukan pendidikan formal sebagai bekal dasar, dan pendidikan informal atau keluarga yang akan memberikan pengalaman nyata tentang bagaimana mengolah dan mengamalkan kepribadian yang baik dengan tetap mempertahankan keimanan dan ketaqwaan kepada Allah Swt. Oleh karena itu, orang tua harus berusaha keras untuk selalu menekankan kepada anak-anak senantiasa berperilaku yang wajar dan santun kepada setiap insan.

\section{Kesimpulan}

Pendidikan keluarga sebagai pondasi awal kehidupan akademis perlu didukung oleh lingkungan sekitar yang berusaha membentuk bangsa yang bermartabat. Interaksi antar anggota keluarga berperan terhadap pembentukan karakter yang bermuara pada terbentuknya akhlak yang mulia dengan mengedepankan sisi-sisi religiusitas dan terciptanya hubungan hablum minallah

${ }^{30}$ M. Arifin. Hubungan Timbal Balik Pendidikan Agama di Lingkungan Keluarga dan Sekolah, (Jakarta: Bulan Bintang, 1978). Hlm. 103 
dan hablum minannaas. Peran orang tua sangat urgen untuk membina dan membimbing keluarga agar dapat bersikap dan berperilaku yang santun dengan pembiasaan yang terus dipandu dan diawasi secara ketat untuk menjalankan tanggung jawab yang utama. Jika keluarga dapat menjalankan tugas utama membentuk karakter yang mulia, maka keluarga telah berhasil menjalankan pendidikan informal yang dampaknya akan signifikan dimana keluarga selaras dengan tujuan pendidikan yang berlandaskan panutan dan tuntunan dalam berperilaku sehari-hari.

\section{Daftar Rujukan}

Ahmadi, Abu. 2007. Sosiologi Pendidikan. Jakarta: Rineka Cipta

Al-Hasan, Yusuf Muhammad. 1997. Pendidikan Anak dalam Islam. Jakarta: Yayasan Al-Sofwa

An Nahlawi, Abdurrahman. 1996. Pendidikan Islam di rumah, Sekolah dan Masyarakat. Cet ke-2. Jakarta: Gema Insani Press

Arifin, M. 1978. Hubungan Timbal Balik Pendidikan Agama di Lingkungan Keluarga dan Sekolah. Jakarta: Bulan Bintang

Ch, Mufidah. Psikologi Keluarga Islam berwawasan Gender. Malang: UIN Press

Daradjat, Zakiah. 1994. Pendidikan Islam Dalam Keluarga dan Sekolah. Cet. 1 Jakarta: Ruhama

Daulay, Haidar Putra. 2004. Pendidikan Islam Dalam Sistem Pendidikan Nasional di Indonesia. Jakarta: Kencana

Djamarah, Syaiful Bahri. 2014. Pola komunikasi Orang Tua dan Anak Dalam Keluarga. Jakarta: Rineka Cipta

Hasan, M. Tholhah. 2009. Pendidikan Anak Usia Dini Dalam Keluarga. Jakarta: Mitra Abadi Press

Hasbullah. 2011. Dasar-Dasar Ilmu Pendidikan. Bandung: PT Raja Grafindo Persada Helmawati, 2016. Pendidikan Keluarga Teoritis dan Praktis. Bandung: PT. Remaja Rosdakarya 
Siti Yumnah

Ihsan, Fuad. 2008. Dasar-Dasar Kependidikan. Jakarta: Rineka Cipta

Langgulung, Hasan. 1986. Manusia dan Pendidikan Suatu Analisa Psikologi, Filsafat dan Pendidikan. Jakarta: Pustaka Al-Husna

Mujib, Abdul dan Mudzakkir, Jusuf. 2008. Ilmu Pendidikan Islam. Jakarta: Kencana Media Group

Nata, Abuddin. 2005. Tokoh-Tokoh Pembaharuan Pendidikan Islam di Indonesia. Jakarta: PT Raja Grafindo Persada

Sadulloh, Uyoh. 2011. Pedagogik (Ilmu Mendidik). Bandung: Alfa Beta

Syarwani, Kasyful Anwar. 2014. Pendidikan Anak Dalam Islam. Surabaya: Muara Progresif

Tafsir, Ahmad. 2000. Ilmu PendidikanDalam Prespektif Islam. Bandung: PT Remaja Rosdakarya 